\title{
Climate Change: The Science Behind Greta Thunberg and Fridays for Future
}

Rainer W. Kühne

Bürgerstr. 4, 38118 Braunschweig, Germany

kuehne70@gmx.de

\begin{abstract}
Climate activist Greta Thunberg started her Skolstrejk för Klimatet on 20 August 2018. Her activity inspired the weekly international demonstrations of Fridays for Future. In this paper I review the scientific argumentation that justifies the demonstrations.
\end{abstract}

\section{Keywords}

Anthropocene, global warming, climate change, Hothouse Earth, Greta Thunberg, Luisa Neubauer, Fridays for Future, Nobel Peace Prize

\section{Short History of Fridays for Future}

Swedish climate activist Greta Thunberg startet her Skolstrejk för Klimatet on 20 August 2018 at the Mynttorget in her hometown Stockholm. According to her book which was published in English [1], Spanish [2], French [3], German [4], and Catalan [5] she held her first public speech on 8 September 2018 in Stockholm within the framework of the Peoples Climate March. In this first public speech she pointed out that her motivation to start the Skolstrejk för Klimatet was a scientific paper that was published in June 2017 and which stated that there was only three years time to reach the goal of the Paris agreement of 2015 to hold global warming below two centigrades above the pre-industrial levels of AD 1850. This paper is ref. [6].

Just two weeks before Greta Thunberg started her Skolstrejk för Klimatet, there appeared a scientific paper on 6 August 2018 which predicted that global warming can cause a Hothouse Earth with global average temperature much higher than that of any interglacial during the past 1.2 million years and sea levels higher than at any time during the past 10,000 years [7].

Greta Thunberg's Skolstrejk för Klimatet inspired the weekly demonstrations of Fridays for Future which started in The Hague (The Netherlands) on 4 September 2018 and in Berlin (Germany) on 14 September 2018. Greta Thunberg met Luisa-Marie Neubauer at the 24th Conference of the Parties to the United Nations Framework Convention on Climate Change (COP24) in Katowice (Poland) on 3 December 2018. As a result, Luisa-Marie Neubauer initiated Fridays for Future demonstrations in a number of cities and towns, so that it became a mass movement in Germany and elsewhere.

Fridays for Future has since then been supported by a number of groups. One of them is Scientists for Future which has been founded by Gregor Hagedorn in March 2019. The program of Scientists for Future has been signed by 26,800 scientists including me [8, 9]. 
Gregor Hagedorn and collaborators published on 12 April 2019 a paper in the scientific research journal "Science" in support of Fridays for Future [10]. This paper has been signed in support by some 3,000 scientists including me [11].

Scientists for Future is not actually new. Its forerunner was March for Science which demonstrated worldwide on 22 April 2017. Its German declaration called Science March Germany was signed by more than 1,000 scientists including me $[12,13]$.

In February 2019 it was announced that Greta Thunberg was nominated for the Nobel Peace Prize.

On 15 May 2019 the University of Mons (Belgium) announced that it will award an honory doctorate to Greta Thunberg.

On 7 June 2019 Amnesty International announced that it will award its Ambassador of Conscience Award to Greta Thunberg and Fridays for Future.

On 12 July 2019 the Royal Scottish Geographical Society awarded the Geddes Environment Medal to Greta Thunberg.

\section{Scientific Motivation}

My interest in global warming started in February 1989, when I read a paper in the popular science magazine "Sterne und Weltraum". The content and conclusions of this paper sound as if they have been written by a Fridays for Future activist in 2019. However, it has been authored by Erhard Keppler already in January 1989. This paper states [14]:

If the global average temperature rises by two centigrades above that of the pre-industrial time around AD 1850, then:

(1) the sea level would rise by several meters, because of the melting of glaciers and arctic and antarctic ice,

(2) deserts would increase in size,

(3) the permafrost in arctic regions would thaw and thereby liberate carbon dioxide and methane.

Erhard Keppler suggested the following measures:

(1) reduction of the emission of carbon dioxide by $2 \%$ per year,

(2) stop clearing tropical rain forests,

(3) reafforest,

(4) reduce consumption of meat and rice, because the cultivation of rice generates methane. 
Moreover Erhard Keppler summarized the evidence of global warming between AD 1880 and 1980 according to Ref. [15] and the evidence of the increment of the concentration of atmospheric carbon dioxide since AD 1750 according to Refs. [16, 17].

\section{References}

[1] G. Thunberg: No One is Too Small to Make a Difference (Penguin, 2019).

[2] G. Thunberg: Cambiemos el mundo (Lumen, 2019).

[3] G. Thunberg: Rejoignez-nous (Kero, 2019).

[4] G. Thunberg: Ich will, dass ihr in Panik geratet! Meine Reden zum Klimaschutz (Fischer, 2019).

[5] G. Thunberg: Canviem el mon \#vagapelclima (Destino, 2019).

[6] C. Figueres et al.: Three years to safeguard our climate. Nature 546 (2017) 593-595.

[7] W. Steffen et al.: Trajectories of the Earth system in the Anthropocene. Proceedings of the National Academy of Sciences of the United States of America 115 (2018) 8252-8259.

[8] Scientists for Future (2019).

https://www.scientists4future.org/stellungnahme/unterschriften/

[9] permanent link for Scientists for Future (25 April 2019). http://archive.is/VHzrG

[10] G. Hagedorn et al.: Concerns of young protesters are justified. Science 364 (2019) 139-140.

[11] G. Hagedorn et al.: Supplementary Materials for Concerns of young protesters are justified. Science 364 (2019) 139-140.

https://science.sciencemag.org/highwire/filestream/725241/field_highwire_adjunct_files/0/a ax3807-Hagedorn-SM.pdf

[12] March for Science (2017). https://marchforscience.de/unterstuetzer/

[13] permanent link for March for Science (20 April 2017). http://archive.is/OTQk7

[14] E. Keppler: Klimaentwicklung und mögliche Vermeidungsstrategien. Sterne und Weltraum 1 (1989) 21-25.

[15] J. Hansen and S. Lebedeff: Global surface air temperature: Update through 1987. Geophysical Research Letters 15 (1988) 323-326.

[16] A. Neftel et al.: Evidence from polar ice cores for the increase in atmospheric $\mathrm{CO} 2$ in the past two centuries. Nature 315 (1985) 45-47.

[17] D. Raynaud and J. M. Barnola: An antarctic ice core reveals atmospheric $\mathrm{CO} 2$ variations over the past two centuries. Nature 315 (1985) 309-311. 